\title{
WACANA KEKUASAAN DALAM UPACARA SIRAMANDAN NGALUNGSUR GENI DI DEsa daNGIANG GARUT
}

\section{THE POWER DISCOURSE IN SIRAMAN AND NGALUNGSUR GENI CEREMONIES IN DANGIANG VILLAGE GARUT}

\author{
Ani Rostiyati \\ Balai Pelestarian Nilai Budaya Jawa Barat \\ Jl. Cinambo No. 136, Ujungberung, Bandung. \\ e-mail: anirostiyati@yahoo.com
}

DOI: $10.30959 /$ patanjala.v12i2.645

\begin{abstract}
Abstrak
Kajian ini bertujuan mengungkap bagaimama wacana kuasa bekerja dalam upacara Siraman dan Ngalungsur Geni. Wacana kuasa ditelusuri dari relasi pemimpin adat (kuncen dan leluhur) dengan masyarakat Desa Dangiang. Dalam kajian ini menggunakan metode deskriptif explanatory dan teknik analisis data secara kualitatif interpretatif, yaitu mengangkat berbagai fenomena, kemudian diinterpretasi dengan teori dari Foucault tentang kekuasaan yang dikonstruksi secara positif dan tidak represif. Data yang digunakan merupakan hasil wawancara mendalam pada informan, observasi pada saat upacara berlangsung, pengambilan foto, dan studi pustaka. Hasil dari kajian ini adalah kekuasaan dalam pelaksanaan upacara Siraman dan Ngalungsur Geni, dikonstruksi secara dinamis, positif, dan tidak represif yakni kekuasaan yang terpusat pada pemimpin adat kuncen yang didistribusi pada semua warga peserta upacara. Simbol dari distribusi kekuasaan tersebut adalah semua peserta merasakan adanya keberkahan yang didapat dari doa kuncen dan air bekas cucian benda-benda pusaka milik leluhur Desa Dangiang.
\end{abstract}

Kata kunci: wacana, kekuasaan, upacara Siraman dan Ngalungsur Geni, Desa Dangiang Garut.

\begin{abstract}
The research aims to reveal how the power discourse works through Siraman and Ngalungsur Geni ceremonies. The power discourse can be traced through the relationship between traditional leaders (kuncen and ancestors) and the people of Dangiang Village. The study uses descriptive explanatory methods and interpretative qualitative data analysis techniques. The researcher first raises the phenomenon to be interpreted with Foucault's theory of positive and non-repressive constructed power. The data used are the results of in-depth interviews with informants, observations during the ceremonies, photos, and literature study. The research reveals that power during Siraman and Ngalungsur Geni ceremonies has been constructed dynamically, positively, and unrepressively. The power centered on traditional leader 'kuncen' is even distributed to all citizens participating in the ceremonies. The distribution of power is reflected when all ceremony participants can feel both the blessings of the prayers offered by the 'kuncen' and the water used for washing the heirlooms belonging to the ancestors of Dangiang Village.
\end{abstract}


Keywords: discourse, power, Siraman and Ngalungsur Geni ceremonies, Dangiang village Garut.

\section{A. PENDAHULUAN}

Tulisan ini menarasikan salah satu upacara adat Siraman dan Ngalungsur Geni di Desa Dangiang Kabupaten Garut, yang pelaksanaannya sarat dengan makna, nilai, simbol, dan wacana kekuasaan yang menarik dilihat dalam hubungannya dengan ditribusi kekuasaan. Upacara tradisional pada umumnya mempunyai tujuan untuk menghormati, mensyukuri, memuja dan minta keselamatan pada leluhur (karuhun) dan Tuhannya. Demikian pula upacara Siraman dan Ngalungsur Geni yang dilakukan masyarakat Desa Dangiang Kecamatan Banjarwangi Kabupaten Garut setahun sekali tiap tanggal 14 bulan Maulud. Upacara ini bertujuan sebagai ungkapan rasa syukur pada Tuhan YME dan penghormatan pada leluhur serta tinggalannya yang berupa benda-benda pusaka. Dalam pelaksanaannya, mereka pergi ke makam leluhur Eyang Batara Turus Bawa yang diyakini sebagai pendiri dari Desa Dangiang, mencuci benda-benda pusaka milik leluhur di Sungai Cidangiang, membersihkan Joglo tempat menyimpan benda-benda pusaka, melaksanakan hantaran tuang (tumpeng sesaji) dan doa bersama.

Pelaksanaan upacara Siraman dan Ngalungsur Geni tersebut memiliki nilai religius dan kesakralan yang penting bagi masyarakat Dangiang. Masyarakat Dangiang, sejak dahulu hingga kini secara rutin melaksanakan upacara tersebut. Jika tidak melaksanakan, mereka percaya akan mendapatkan bencana penyakit dan gagal panen. Selain itu akan terdengar suara bergemuruh di sekitar rumah Joglo, tempat menyimpan benda-benda pusaka. Tentu saja dalam pelaksanaan upacara tersebut terdapat sesaji yang dipercaya sebagai penghubung dengan para leluhur, agar doanya dikabulkan oleh Tuhan YME.

Seluruh rangkaian upacara tersebut memiliki makna, nilai, dan simbol dari sebuah praktik kebudayaan, seperti dinding transparan yang dikonstruksi oleh kekuasaan. Ia merupakan hasil dari sebuah relasi kuasa. Praktik kebudayaan sebenarnya merupakan arena perebutan kekuasaan, ada pihak yang paling dominan dan ada yang dimarjinalkan. Makna dan kebenaran tersebut dibentuk dalam polapola kekuasaan (Barker, 2010: 372). Demikian pula pada upacara adat Siraman dan Ngalungsur geni, salah satu ritual yang mengandung makna, nilai, dan kebenaran sebuah peristiwa kebudayaan yang dikonstruksi oleh masyarakat sebagai rasa syukur pada Tuhan YME dan leluhur atas keselamatan dan panen yang diperoleh. Bentuk upacara Siraman dan Ngalungsur Geni merupakan peristiwa budaya yang di dalamnya terdapat pelaku dan benda-benda budaya artefak yang tidak diam, terus tumbuh bersama masyarakatnya. Ia sebagai warisan budaya yang masih direproduksi oleh generasinya. Artinya masyarakat melakukan reproduksi dari apa yang telah dilakukan oleh leluhurnya (Mudhoffir, 2013).

Dalam praktiknya, proses pemaknaan atau konstruksi nilai dalam reproduksi memiliki jaringan relasi kekuasaan, karena kekuasaan salah satunya merupakan suatu model komunikasi yang berbentuk simbol (Muis, 2010). Dalam hal ini proses reproduksi dihadapkan pada suatu hubungan masyarakat dengan benda budaya (benda-benda pusaka, Joglo tempat keramat, dan sesaji), yang diwariskan dalam bentuk simbol-simbol. Reproduksi upacara sebagai tempat relasi kuasa bekerja, maka tentunya memiliki model relasi kuasa pada reproduksinya. Upacara tersebut memiliki lapisan simbol yang tebal, maknanya saling terhubung satu sama lain. Sebagai karya manusia, upacara tersebut menempati tempat penting bagi masyarakatnya. Sehingga yang menjadi tujuan utama dalam kajian di sini adalah bagaimama wacana kuasa bekerja dalam upacara Siraman dan Ngalungsur Geni pada masyarakat Desa Dangiang Garut. 
Wacana kuasa tersebut ditelusuri antara individu dalam kelompok masyarakat dan masyarakat dengan benda upacara adat tersebut. Dengan demikian tujuan dari kajian ini adalah untuk memahami wacana kuasa, dalam hal ini leluhur dan pemimpin adat Kuncen dalam upacara adat Siraman dan Ngalungsur Geni di Kabupaten Garut.

Perlu dikemukakan di sini, bahwa kajian tentang Siraman dan Ngalungsur Geni pernah saya tulis dalam Jurnal Patanjala Vol.3. No 1 Maret 2011. Fokus dalam tulisan tersebut adalah mendeskripsikan prosesi upacara dan makna upacara terhadap masyarakat Desa Dangiang. Berdasarkan tulisan tersebut, informasi tentang prosesi upacara Siraman dan Ngalungsur Geni sudah diungkap. Namun, saya melihat masih ada peluang untuk membahas upacara Siraman dan Ngalungsur Geni dari sisi yang berbeda, khususnya untuk membahas wacana kuasa pada upacara adat. Seperti yang diungkapkan oleh Priyatna dalam Rostiyati (2017) bahwa sebuah kajian bisa dilihat dari berbagai sisi, bergantung dari sudut pandangnya dan ini merupakan satu tindakan ideologis yang terbuka.

Untuk mengkaji secara khusus tentang wacana kuasa pada upacara tersebut, dibutuhkan data prosesi upacara sebagai gambaran umum karena merupakan bagian penting untuk mendukung tulisan ini. Untuk itu, maka gambaran singkat tentang prosesi upacara Siraman dan Ngalungsur Geni di Desa Dangiang, akan diambil dari beberapa tulisan saya sebelumnya (Rostiyati, 2011). Diawali dengan melakukan penelitian dan perekaman upacara tersebut pada tahun 2010 dan setelah dikonfirmasi lagi pada tahun 2020 upacara tersebut masih dilakukan sampai sekarang. Secara rutin tiap tahun pada bulan Maulud, mereka melaksanakan upacara tersebut. Jika tidak melakukan ritual tersebut, maka dipercaya akan terjadi kegagalan panen dan wabah penyakit. Ketertarikan ini menjadikan alasan penulis untuk melihat kembali upacara Siraman dan Ngalungsur Geni dari sisi lain yakni bagaimana wacana kuasa bekerja dalam upacara adat tersebut

Dalam kajian ini ada beberapa teori kekuasaan yang digunakan. Ada beberapa teori dan hasil penelitian mengenai kekuasaan, di antaranya Anderson (2015), melakukan penelitian tentang kekuasaan Jawa di Indonesia kaitannya dengan kesadaran nasional. Seseorang yang berkuasa harus mempunyai objek-objek atau orang-orang yang mengelilinginya. Selama benda-benda yang dianggap keramat dan orang-orang tersebut berada dalam istana, maka kekuasaannya terserap oleh si penguasa itu. Benda-benda merupakan simbol memiliki kekuatan dalam "membentuk dunia" dan simbol mempunyai arti yang sangat penting dalam kehidupan manusia.

Bagi Danesi (2004), simbol sangat erat hubungannya dengan manusia. Pembahasannya tentang "The Power of Symbols", bahwa manusia adalah animal symbolicum. Hanya dengan menggunakan simbol-simbol, manusia dapat mencapai potensi dan tujuan hidupnya yang tertinggi. Simbol yang paling kuat adalah manusia yang hidup. Manusialah yang menjadi simbol paling kuat dan paling patut dikenangkan, kadang-kadang oleh karena perkataan dan perbuatannya.

Kajian mengenai kekuasaan juga dikaitkan pada relasi antara posisi yang dominan dan marjinal. Kekuasaan merupakan sifat suatu hubungan, bukan sifat-sifat individu. Kekuasaan merupakan suatu model komunikasi yang khas berbentuk tanda (Usop, 1978). Kepatuhan, paksaan, otoritas, dan pengaruh merupakan istilah pokok yang kerap digunakan dalam kajian tentang kekuasaan. Menurut Bae (1995), kepatuhan mengacu pada sikap dan perilaku yang disebabkan oleh kekuasaan. Tindakan tersebut mengesampingkan dirinya sendiri karena sumpah (secara langsung atau tidak) kepada orang lain. Otoritas terletak di antara hak untuk berharap dengan ketaatan (pada) perintah. Karena itulah, Bae mendefinisikan otoritas 
sebagai jenis keunggulan yang mencakup hak (dan/atau kewajiban) yang sah untuk mengendalikan tindakan-tindakan pihak lain di dalam sistem hubungan sosial. Anderson (2015) merumuskan kekuasaan terdapat dari berbagai sumber seperti: kekayaan, status sosial, jabatan formal, organisasi, senjata, populasi, dan sebagainya.

Sebuah tanda bagi Bourdieu (1994: 164), juga dilihat sebagai media dimana kekuasaan berfungsi, salah satunya pada sebuah ritual atau upacara. Tanda-tanda tersebut media dan tempat, menjadi bagian dari kehidupan konkrit. Kekuasaan sendiri diartikan sebagai kuasa simbolik, yakni berjalannya sebuah kekuasaan tidak nampak, bahkan berada di luar kesadaran. Jika upacara sebagai arena beroperasinya kekuasaan, maka upacara bersifat politis, karena ia mengekspresikan relasi sosial kekuasaan dengan cara menaturalisasi tatanan sosial sebagai suatu 'fakta' niscaya, sehingga mengaburkan relasi eksploitasi di dalamnya. Artinya upacara sebagai tempat mengartikulasikan kekuasaan. Melalui upacara relasi kuasa tidak nampak (tak disadari), yang disebut simbolic power. Kekuasaan simbolik tersebut dibahasakan oleh Antonio Gramsci sebagai hegemoni yaitu jika kuasa simbolik bicara soal ketidaksadaran, maka dalam hegemoni sama artinya dengan menikmati. Kekuasaan menjalankan otoritas sosial dan kepemimpinannya atas kelas-kelas subordinat melalui kombinasi antara kekuatan dengan persetujuan (Barker, 2010). Bagi Gramsci, kekuasaan dapat dilanggengkan melalui strategi hegemoni, yakni peran kepemimpinan intelektual dan moral untuk menciptakan ide-ide dominan. Kekuasaan diperoleh lewat hegemoni ide-ide (dalam wilayah budaya) yang didasarkan atas mekanisme konsensus (Barker, 2010: 62).

Dari beberapa referensi konsep dasar tentang "power", ditemukan beberapa persoalan pokok, di antaranya: (1) Kekuasaan merupakan sebuah relasi (hubungan) yang bekerja dalam sebuah interaksi sosial; (2) Dalam kuasa simbolik, kekuasaan beroperasi dalam sistem tanda atau simbol; (3) Kekuasaan adalah hegemoni, di mana pihak yang dikuasai menikmati beroperasinya sebuah kekuasaan (Hadi, 2018).

Dari sejumlah teori di atas, persoalan pokok tentang "power" tersebut, secara metodis akan digunakan sebagai pisau untuk menganalisis wacana kekuasaan dalam upacara Ngalungsur Geni di Garut. Dalam arti untuk menjawab pertanyaan, bagaimana wacana kekuasaan yang bekerja dalam upacara tersebut. Untuk memahami wacana kekuasaan yang terdapat pada upacara tersebut, saya cenderung mengikuti pemikiran Foucault yang memiliki pandangan tentang kuasa yang berbeda dengan pemikiran lainnya, seperti Bourdieu yang terkenal dengan konsepnya mengenai kekuasaan simbolik (symbolic power) yang tidak lain adalah kekerasan simbolik maupun Gramsci dengan konsep tentang kekuasaan hegemoni. Berbeda dengan Bourdieu dan Gramsci, Foucault memberikan ruang bagi setiap orang atau individu dan kelompok masyarakat untuk mengaktualisasikan diri secara bebas apa adanya. Konsep kekuasaan Foucault (2002) melihat kekuasaan sebenarnya ada di mana-mana, tidak dapat diklaim milik kelompok tertentu karena tidak dapat disimpan dan dibagi-bagi. Hal lain yang menarik dari Foucault adalah kekuasaan tidak bekerja secara negatif dan represif, tetapi dengan cara yang positif dan produktif. Tampak di sini bahwa Foucault secara tegas menentang pemahaman tentang kekuasaan yang cenderung dimaknai milik kelompok tertentu, hegemonik, dan menindas atau digunakan sewenang-wenang.

\section{B. METODE PENELITIAN}

Kajian ini menggunakan metode deskriptif explanatory yakni kombinasi antara penelitian deskriptif dan explanatory. Penelitian deskriptif menjawab pertanyaan "apa", sedangkan eksplanasi menjawab pertanyaan "mengapa" dan "bagaimana". 
Teknik analisis data secara kualitatif interpretatif, yaitu mengangkat berbagai fenomena dan realitas sosial, kemudian diinterpretasi dengan teori simbol dan kekuasaan yang mendapatkan pijakan kuat pada realitas, bersifat kontekstual, dan historis (Somantri, 2005: 64).

Data yang digunakan merupakan hasil wawancara mendalam pada beberapa informan sebagai data primer, yakni pemimpin adat kuncen dan wakil kuncen serta tokoh masyarakat lain. Data ini kemudian akan dianalisis lebih dalam mengenai wacana kekuasaan, dalam hal ini leluhur dan pemimpin adat kuncen. Selain wawancara, juga observasi (pengamatan) dan perekaman di lapangan pada saat prosesi upacara berlangsung, pengambilan foto, dan studi pustaka.

\section{HASIL DAN BAHASAN \\ 1. Ritual dan Wacana Kuasa}

Pada upacara Siraman dan Ngalungsur Geni di Desa Dangiang Garut tampak adanya legitimasi pemimpin adat kuncen dalam hubungannya dengan rakyat. Tulisan ini mendeskripsikan pemikiran masyarakat Dangiang mengenai kekuasaan seorang kuncen yang dianggap pemimpin adat yang harus dihormati. Dalam konteks ini melihat bagaimana praktik kekuasaan khususnya mengenai keabsahan atau legitimasi hubungan penguasa dengan rakyat dalam kehidupan masyarakat Dangiang. Apa ada relasi dan konstruksi kekuasaan yang berpusat pada kuncen, wakil kuncen dan leluhurnya. Dalam arti, kekuatan leluhur dan kuncen menyiratkan adanya relasi kuasa dan konstruksi kekuasaan dalam ritual tersebut.

Menurut Turner (1967) ritual merupakan transformasi sikap dari yang profan (nyata) kepada sesuatu yang sakral (kudus). Hal ini juga diungkapkan oleh Durkheim (2005) yang membahas tentang agama paling primitif yang dikenal oleh manusia yakni totemisme. Totemisme adalah kepercayaan terhadap hewan atau tumbuhan yang dianggap memiliki roh leluhur. Bentuk hewan atau tumbuhan dilukis atau digambar dalam tubuh manusia, tindakan ini merupakan upaya untuk mengubah sesuatu yang sifatnya profane (tidak suci) menjadi sacred (sakral atau suci).

Pada ritual terdapat simbol-simbol perilaku dan perasaan yang turut membentuk pribadi mereka untuk memuja atau melakukan ritual. Dalam hal ini, diyakini bahwa terdapat suatu kekuatan yang lebih besar dan kuat (the supreme being) di luar diri manusia. Melalui pelaksanaan ritual, manusia (orang yang melakukan ritual) merasa akrab atau dekat dengan subjek yang kudus dan mendapat perlindungan atau rasa aman. Demikian pula masyarakat Dangiang merasa akrab dan dekat dengan kekuatan leluhur dan pemimpin adat kuncen, sehingga mendapatkan rasa aman dan perlindungan.

Adapun istilah wacana diterjemahkan dari kata discourse yang digunakan oleh para linguistik yang menunjuk pada suatu rangkaian sinambung bahasa yang lebih besar dari kalimat (Oetomo, 1993:3). Dalam perkembangannya, istilah wacana digunakan secara luas oleh semua bidang ilmu sosiologi. Menurut Abdullah (2009: 285), wacana kekuasaan dalam ritual adalah simbol-simbol dalam suatu ritual (komunal) berupa ucapan, mantra, peran, busana, nyanyian atau tarian yang diproduksi dan menyiratkan representasi dan atau konstruksi kekuasaan yang disadari atau tidak disadari telah digunakan untuk memperoleh, mempertahankan, dan mengendalikan yang lain. Dalam hal ini, sesaji, peralatan ke makam, tumpeng hantaran tuang, benda-benda pusaka milik leluhur, Joglo tempat menyimpan benda pusaka, alat mencuci benda pusaka, air Sungai Cidangiang tempat mencuci pusaka, mantra yang diucapkan kuncen, batu keramat, makam keramat leluhur, ini merupakan representasi dari kekuasaan yang digunakan oleh pemimpin adat kuncen untuk memperoleh pengakuan dan mengendalikan masyarakat.

Hal ini sesuai dengan penjelasan Foucault sebagaimana dikutip oleh Barthes 
(2085: 487) yang memberikan pokok pemikiran mengenai kekuasaan. Pertama, kuasa bukan milik melainkan fungsi. Kedua, kuasa tidak dapat dialokasikan tetapi terdapat di mana-mana. Ketiga, kuasa tidak selalu bekerja melalui penindasan dan resepsi, tetapi terutama melalui normalisasi dan regulasi. Keempat, kuasa tidak bersifat destruktif melainkan produktif. Dalam pandangan Foucault, kuasa tidak dimiliki, tetapi dipraktikkan dalam suatu lingkup tertentu dan terdapat posisi yang strategis memiliki relasi yang berkaitan satu dengan lainnya. Secara tegas mengatakan bahwa di mana saja ada aturan atau regulasi dan ada manusia yang memiliki hubungan dengan dunia luas, di situ kuasa bekerja, Menurutnya, kuasa tidak dapat dilihat dari perspektif bahwa seseorang menguasai dari yang lain, kuasa juga tidak bekerja secara negatif dan represif melainkan dengan cara positif. Dalam hal ini, kuasa dapat memproduksi realitas, kuasa memproduksi lingkup objek dan ritus kebenaran. Bagi Foucault, kuasa bukan hubungan subjektif searah dan kemampuan seorang atau kelompok untuk memaksakan kehendak kepada orang lain.

\section{Prosesi Upacara Siraman dan Ngalungsur Geni}

Prosesi upacara Siraman dan Ngalungsur Geni yang akan dipaparkan berikut ini adalah inti sari dari tulisan saya sebelumnya (Rostiyati, 2017:33-47), untuk memberi gambaran umum karena menjadi bagian penting untuk mendukung kajian ini.

Desa Dangiang terletak di Kecamatan Banjarwangi Kabupaten Garut. Desa Dangiang, cukup jauh letaknya dari Kabupaten Garut, berjarak kurang lebih 60 $\mathrm{km}$ dari daerah Kabupaten dan $11 \mathrm{~km}$ dari Kecamatan. Dari Kabupaten Garut memakan waktu kurang lebih 2 jam dan dari Kecamatan memakan waktu kurang lebih 0.5 jam.

Masyarakat Desa Dangiang, hanya tahu sejarahnya dari pemimpin adat bahwa leluhurnya bernama Eyang Batara Turus
Bawa yakni seorang prajurit Mataram, yang menghindari kejaran kompeni dan bersembunyi di desa tersebut. Menurut sejarahnya, Eyang Batara Turus Bawa dan keluarganya berkelana dari Mataram sampai ke hilir Desa Bojong Kecamatan Banjarwangi Kabupaten Garut. Mereka mandi sebentar di sungai dan menyimpan sebuah meriam si Guntur Geni di Gunung Tingaragung di dalam rumpun bambu kuning. Meriam tersebut diharapkan akan diambil anak cucunya kelak. Mereka melanjutkan perjalanan ke Desa Dangiang yang hanya dihuni oleh seorang yang berasal dari Mekah dan merupakan sahabat lama bernama Imam Safei. Di desa tersebut, Eyang Batara Turus Bawa mempunyai keturunan sepuluh anak, salah satunya yakni anak pertama bernama Sanghiang Resik Rarang.

Sanghiang Resik Rarang menikah dengan Raja Galuh Pakuan (Guru Gantangan) dan mempunyai tiga anak yaitu Sembah Dalem Tanu Datar, Sunan Batu Wangi, dan Eyang Bungsu. Sembah Dalem Tanu Datarlah yang kemudian menurunkan masyarakat Dangiang sekarang ini. Sedangkan Eyang Batara Turus Bawa dan pengiringnya wafat, mereka dimakamkan di Kampung Datar. Merekalah yang secara turun-temurun dihormati oleh masyarakat Desa Dangiang sebagai cikal bakal atau leluhur Desa Dangiang.

Upacara Siraman dan Ngalungsur Geni memiliki makna mencuci (siraman) dan meneruskan (ngalungsur) kesaktian benda-benda pusaka milik leluhur, sekaligus sebagai penghormatan kepada leluhur sebagai cikal bakal pendiri desa.

Sembah Dalem Tanu Datar menurunkan beberapa keturunan, dimulai dari pemimpin adat (kuncen) pertama yakni Sembah Naga Bali sampai terakhir Ajengan Entang. Sembah Naga Bali adalah orang pertama yang mengambil benda pusaka Guntur Geni, kemudian benda pusaka tersebut disimpan di Desa Dangiang (di rumah Joglo). 

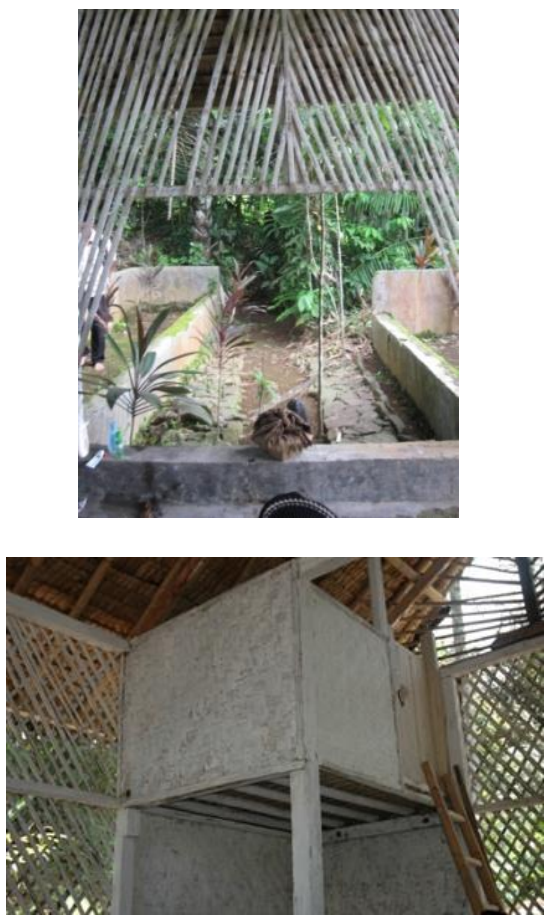

Gambar 1. Makam Leluhur Eyang Batara Turus Bawa dan Joglo, tempat penyimpanan benda pusaka.

Sumber: Dok. penulis, 2010.

Diceritakan, seminggu menjelang tanggal 14 Maulud, meriam Si Guntur Geni akan menjelma menjadi senjata yang mengeluarkan bunyi gemuruh seperti suara guntur. Ini sebagai tanda akan dilaksanakannya upacara Ngalungsur Geni.

Upacara Siraman dan Ngalungsur Geni dilaksanakan pada setiap bulan Maulud, hari Senin. Hari Senin, dianggap hari baik yakni kelahiran Nabi Muhammad SAW. Apabila upacara tidak dapat dilaksanakan pada hari Senin oleh karena berbagai hal, maka upacara dapat dilaksanakan pada hari Kamis. Ada lima tahapan dalam upacara Ngalungsur Geni yaitu: ngalirap (membuat pagar), membuka sejarah desa, ziarah kubur, mencuci benda-benda pusaka, dan doa bersama.

Pagi hari sebelum upacara dilaksanakan, masyarakat melaksanakan ngalirap, yakni membuat pagar baru di sekitar rumah joglo dengan cara bergotong-royong dan membersihkan masjid, jalan, dan makam. Kegiatan selanjutnya yakni malam hari, membuka sejarah desa oleh kuncen dan warga yang berkumpul di Joglo untuk mengadakan pengajian dan menceritakan sejarah Desa Dangiang. Pagi harinya berziarah ke makam leluhur dan mencuci benda-benda pusaka di Sungai Cidangiang dengan dihadiri semua warga Dangiang untuk meminta berkah dari air cucian benda pusaka. Terakhir, adalah doa dan makan bersama dengan diikuti hampir semua warga Dangiang yang berkumpul di Joglo dengan membawa tumpeng hantaran tuang yang ditaruh di bokoko, rantang atau baskom.
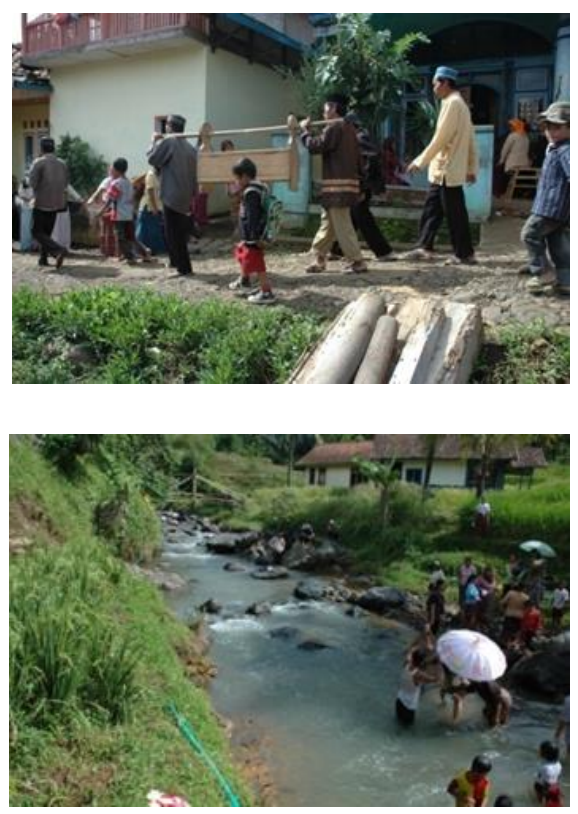

Gambar 2. Pengangkutan benda pusaka menuju Sungai Cidangiang.

Sumber: Dok. penulis, 2010.

Adapun kegiatan persiapan dilakukan sejak seminggu sebelum puncak upacara, yakni berupa musyawarah antara kuncen, wakil kuncen, dan tokoh masyarakat. Mereka bermusyawarah untuk menentukan tanggal pelaksanaan upacara dan biaya, dan hasil musyawarah diumumkan kepada warga masyarakat melalui pengeras suara yang ada di masjid. Upacara tersebut 
dilaksanakan secara swadaya masyarakat dan besarnya sumbangan bergantung keikhlasan warga.

Sementara itu, kaum ibu disibukkan dengan persiapan membeli bahan-bahan untuk membuat tumpeng (hantaran tuang), juga membuat kue dan sesaji. Sesaji untuk dibawa ke makam leluhur berupa perlengkapan kosmetik seperti hand body, minyak wangi, krem wajah, talk, dan krem rambut dan seureuh (daun sirih). Sesaji ini dipercaya masyarakat agar doa yang disampaikan untuk leluhur dikabulkan oleh Tuhan YME.
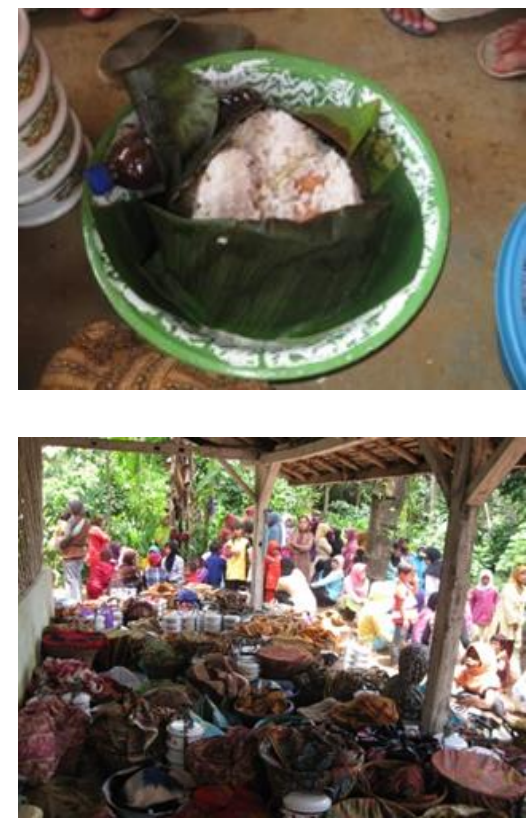

Gambar 3. Tumpeng, hantaran tuang, dan sesaji di makam.

Sumber: Dok. penulis, 2010.

Setelah melakukan ngalirap, membuka sejarah desa, dan ziarah ke makam leluhur, maka dilanjutkan dengan acara pencucian benda pusaka di Sungai Cidangiang. Benda pusaka diturunkan dari Joglo lalu dimasukkan dalam peti dan diangkat menuju Sungai Cidangiang. Benda pusaka yang tersimpan di Joglo berupa meriam, keris, pedang, badik, dan tombak. Warga yang memiliki benda pusaka simpanannya juga ikut dicuci di Sungai Cidangiang. Biasanya benda pusaka milik pribadi pada umumnya berupa pedang. Setelah benda pusaka dicuci, kemudian diangkat kembali ke rumah Joglo untuk membersihkan benda pusaka. Benda pusaka agar tidak berkarat, terlebih dahulu dibersihkan dengan jeruk nipis dan dikeringkan dengan kawul yakni serutan bambu agar cepat kering. Adapun kemenyan digunakan untuk meraja atau doa mantra, dengan harapan agar asap yang membumbung ke atas bisa mengantarkan doa sampai ke Yang Maha Kuasa.
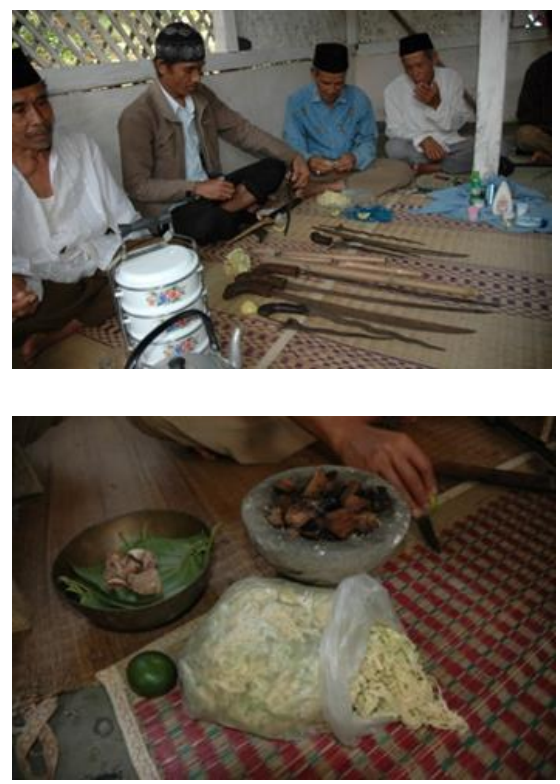

Gambar 4. Sesaji pembersihan benda pusaka. Sumber: Dok. Penulis, 2010.

Pada saat pembersihan benda pusaka di Joglo, semua warga berkumpul di Joglo sambil membawa tumpeng yang ditaruh di boboko, rantang atau baskom. Sangat banyak tumpeng yang terkumpul berisi nasi, lauk pauk, dan beberapa alat kosmetik (bedak, lipstik, minyak wangi, dll). Bagi warga, alat kosmetik yang sudah mendapat doa ini dipercaya agar anaknya dikaruniai wajah cantik dan segera mendapatkan jodoh.

Demikian secara singkat, upacara Siraman dan Ngalungsur Geni di Desa Dangiang Garut. Ditutup dengan ucapan rasa syukur dari kuncen kepada Allah 
Yang Esa atas rahmat dan berkah yang sudah diberikan kepada warga masyarakat Dangiang.

Secara umum pelaku upacara adalah seluruh anak cucu warga Dangiang. Ada beberapa ketentuan yang perlu mendapat perhatian setiap warga yang hendak mengikuti upacara tersebut. Antara lain, peserta ziarah tidak diperbolehkan mengenakan alas kaki, tidak diperbolehkan mengambil bebatuan, dan memetik bunga. Selain itu ada larangan ziarah bagi perempuan yang sedang haid, pejabat pemerintah, tidak boleh membuka peti selain hari Senin dan Selasa bulan Maulud dan harus oleh kuncen. Semua larangan dan pantangan itu harus dipatuhi warga. Mereka harus membersihkan diri dengan mandi, mencuci kaki atau muka, dan berwudhu sebelum masuk ke wilayah makam. Apabila pantangan tersebut dilanggar, dipercaya berakibat hidup sengsara bagi pelanggarnya.

Ada nilai edukasi dalam pantangan atau larangan tersebut, yakni perempuan yang diperbolehkan ziarah dalam keadaan bersih dan suci, agar kompleks makam terjaga kebersihannya, wilayah sekitar makam dimaksudkan agar daerah tersebut terjaga keasriannya, dan dilarang mengambil bebatuan agar daerah tersebut tidak mudah longsor.

Demikian pula sesaji yang terdapat dalam upacara Siraman dan Ngalungsur Geni, terdapat makna yang terkandung di dalamnya, seperti tumpeng berbentuk runcing bermakna ungkapan rasa syukur kepada Yang Esa; daun sirih yang diletakkan di atas makam dimaksudkan sebagai pengganti daun kurma yang digunakan oleh Nabi Muhammad SAW; kosmetik yang baunya wangi bermakna harus bisa mengharumkan nama leluhur dan menjaga nama baik leluhur dengan tidak melakukan hal-hal yang bertentangan dengan adat-istiadat setempat. Kembang mawar dalam sesaji bermakna untuk mengharumkan nama leluhur dan air cucian benda pusaka dipercaya bisa berfungsi sebagai "berkah". Berkah inilah yang menjadi argumentasi dari kajian ini karena kehadiran figur tertentu seperti kuncen, wakil kuncen, leluhur dan tokoh masyarakat menyebabkan para peserta merasa memiliki kekuatan ekstra atas keberkahan yang didapat dari air bekas cucian benda pusaka, sesaji dan doa mantra dari kuncen, yang menyiratkan kekuasaan tertentu.

\section{Wacana Kuasa dalam Upacara Siraman dan Ngalungsur Geni}

Menurut Rumahuru dalam Abdullah (2009:295), kekuasaan merupakan sesuatu yang menegangkan dan tidak dapat dilepaskan dari kehidupan manusia. Praktis, setiap orang tanpa memandang laki-laki atau perempuan, status sosial, besar kecil melekat padanya kuasa yang tampak melalui kata-kata dan ekspresinya (tindakan). Sedangkan wacana diterjemahkan dari kata discourse dan digunakan terutama oleh para lingius di Indonesia yang menunjuk percakapan dan komunikasi verbal. Bahasa merupakan alat yang mengekspresikan seluruh realitas kehidupan manusia, sekaligus sarana efektif untuk mengkonstruksi kekuasaan. Hal ini dimungkinkan karena bahasa merupakan sistem lambang (symbol), isyarat (code), tanda (sign) serta rangkaian lambang suara dan terucap yang kemudian dikembangkan menjadi lambang yang tertulis (Danesi, 2004). Dalam konteks bermasyarakat, kekuasaan menjadi wacana yang menarik.

Wacana kekuasaan menurut pemikiran Foucault seperti sudah dikemukakan di atas, menunjukkan bahwa kekuasaan tidak bekerja secara negatif dan represif tapi dengan cara positif dan produktif. Dalam hal ini, kekuasaan atau kuasa dapat memproduksi realitas, lingkup objek, dan ritus kebenaran. Bagi Foucault, kuasa bukan hubungan subjektif searah dan kemampuan seorang atau kelompok untuk memaksakan kehendak kepada orang lain.

Jika dilihat dari pelaksanaan upacara Siraman dan Ngalungsur Geni, kekuasaan 
dikonstruksi secara dinamis tidak terbatas pada warganya dan tidak terpusat ada di mana-mana. Dalam upacara tersebut, terdapat relasi dan wacana kekuasaan yang sadar, tidak dipaksa, dan tidak dikontrol oleh pihak tertentu atas nama pemimpin atau warga yang dipimpin. Konstruksi kekuasaan pada upacara ini meskipun cenderung mengarah pada pemusatan kuasa yakni leluhur (Eyang Batara Turus Bawa) dan kuncen, tapi kekuasaannya ini didistribusikan untuk menciptakan kekuasaan (kekuatan) baru yang dirasakan oleh semua warga, yakni mereka mendapatkan keberkahan dari doa-doa yang disampaikan kuncen dan dari air bekas cucian benda-benda pusaka milik leluhur.

Air bekas cucian benda pusaka milik leluhur diyakini mendapat keberkahan dari leluhur. Upacara mencuci benda-benda pusaka milik leluhur dimulai pagi hari, diawali dengan pembantu kuncen membuka ruang tempat penyimpanan benda pusaka, membuka peti, lalu mengeluarkan benda-benda pusaka yang ada di dalamnya berupa pedang, meriam, golok, keris, dan tombak. Semua benda pusaka sudah dikeluarkan lalu dibawa ke Sungai Cidangiang yang berjarak 300 meter dari Joglo. Caranya, peti yang berisi benda-benda pusaka dipikul oleh dua orang dan diarak menuju ke Sungai Dangiang dengan diikuti warga dibelakangnya. Setiba di sungai, bendabenda pusaka tersebut dicuci satu persatu, benda-benda pusaka yang disimpan di Joglo dan benda pusaka milik perorangan. Benda-benda pusaka tersebut dicuci atau dimandikan sambil peserta upacara berselawat. Saat benda-benda pusaka dicuci, masyarakat menyeburkan diri di sungai sambil membasuh mukanya dari air bekas cucian tersebut, dengan harapan untuk mendapat berkah. Air cucian tersebut dipercaya bisa membawa berkah seperti menjadi obat segala macam penyakit, bisa menjadikan awet muda, enteng jodoh, memudahkan rizki, panennya berlimpah, naik jabatan, dan lain sebagainya. Sebagai contoh, keris yang sudah dicuci di sungai dikucurkan di atas mata orang yang menderita sakit mata dengan harapan mendapatkan kesembuhan.

Adapun doa-doa dari kuncen yang dianggap memberi keberkahan pada saat berdoa di makam leluhur, di Joglo membuka sejarah desa dengan selawat dan tahlil, membersihkan benda pusaka, dan ijab kabul. Saat acara membuka sejarah desa, kuncen memberi ceramah tentang jati diri manusia (masyarakat Dangiang) dan tentang tujuan upacara. Paparan dari kuncen tersebut dimaksudkan agar warga masyarakat Dangiang mengenal jatidirinya dan tidak mengaburkan makna dari pelaksanaan upacara. Usai paparan tersebut dilanjutkan dengan marhabaan, selawat, tahlil, dan membuka sejarah desa yang juga dipimpin oleh kuncen. Usai acara, kuncen dan beberapa peserta menuju ke makam Eyang Batara Turus Bawa. Keberangkatan mereka ke makam untuk melakukan semedi (bertapa). Mereka bersemedi hingga pagi hari dan dilanjutkan dengan melaksanakan upacara ziarah kubur bersama dengan peserta ziarah lain yang baru datang. Mereka datang dengan membawa perlengkapan kosmetik dan kembang, setelah menempuh perjalanan sejauh 3 kilometer. Jalanan terjal, jalan setapak, dan pematang mereka lalui, bukit mereka daki, demikian pula selokan dan sungai mereka seberangi hingga memakan waktu lebih kurang 1 jam. Setiba di Sungai Cidangiang, 10 meter dari makam, para peserta melepas alas kaki kemudian membersihkan diri dan berwudhu. Beberapa langkah kemudian sampailah peserta di kompleks makam Eyang Batara Turus Bawa. Kuncen meletakkan daun sirih di atas makam dan menjelaskan tujuan ziarah dan peziarah yang mempunyai suatu "maksud", boleh diikrarkan atau cukup di dalam hati ditujukan pada Allah semata. Setelah itu peserta ziarah membuka perlengkapan kosmetik dan berdoa dengan dipimpin kuncen. Minyak wangi yang sudah diberi doa disemprotkan ke makam dan diri 
sendiri, sisanya dikenakan oleh anggota keluarga di rumah. Selanjutnya bagi yang memiliki suatu "maksud yang besar", mereka akan menuju bangunan tempat tersimpannya sebuah batu. Mereka akan menyampaikan maksudnya kepada Allah sekaligus memohon untuk dikabulkan. Ada kepercayaan apabila batu itu bisa terangkat oleh yang mempunyai maksud maka akan terkabullah apa yang diinginkan. Semakin tinggi batu terangkat maka semakin besar harapan untuk bisa terkabul. Ada kepercayaan, doa yang disampaikan kuncen ini akan membuat mereka kuat untuk mengangkat batu tersebut. Demikian pula doa ijab kabul yang disampaikan oleh kuncen, dipercaya dapat memberi keberkahan. Demikian pula tumpeng hantaran tuang yang dibawa warga untuk dimakan bersama keluarga di rumah juga mendapat keberkahan dari doa dan ikrar yang dipanjatkan Kuncen.

Dalam upacara Siraman dan Ngalungsur Geni terdapat 3 unsur yang terlibat aktif. Leluhur Eyang Batara Turus Bawa, Kuncen yang dianggap pemimpin adat dengan tugas utama membaca doa dan memimpin upacara, serta wakil kuncen yang bertugas membantu jalannya upacara. Selain itu ada masyarakat yang ikut dalam upacara, terbagi sebagai peserta aktif dan pasif. Peserta upacara aktif yang terlibat langsung dalam hal ini warga Desa Dangiang, sedangkan peserta pasif berasal dari desa lain yang ikut dalam upacara tersebut. Tampaknya desa lain yang terdekat juga ikut serta ngalap berkah (mencari berkah) dengan mengambil air bekas cucian benda pusaka.

Menurut Magnis-Suseno (2003:3947) keabsahan atau legitimasi kekuasaan dalam masyarakat Desa Dangiang, dalam konteks kekuasaan religius terdapat tiga unsur yaitu Pertama, penguasa harus menunjukkan diri mampu untuk memegang kekuasaannya; Kedua, seseorang hanyalah betul-betul dianggap berkuasa apabila masyarakat di bawah pemerintahannya berada dalam keadaan adil makmur; dan Ketiga, penguasa menunjukkan mutu mental dan sikap budi yang merupakan prasyarat kemampuannya untuk berhubungan dengan alam gaib, yaitu menjalankan kekuasaan tanpa perlu memakai kekuasaan atau tindakantindakan yang kasar.
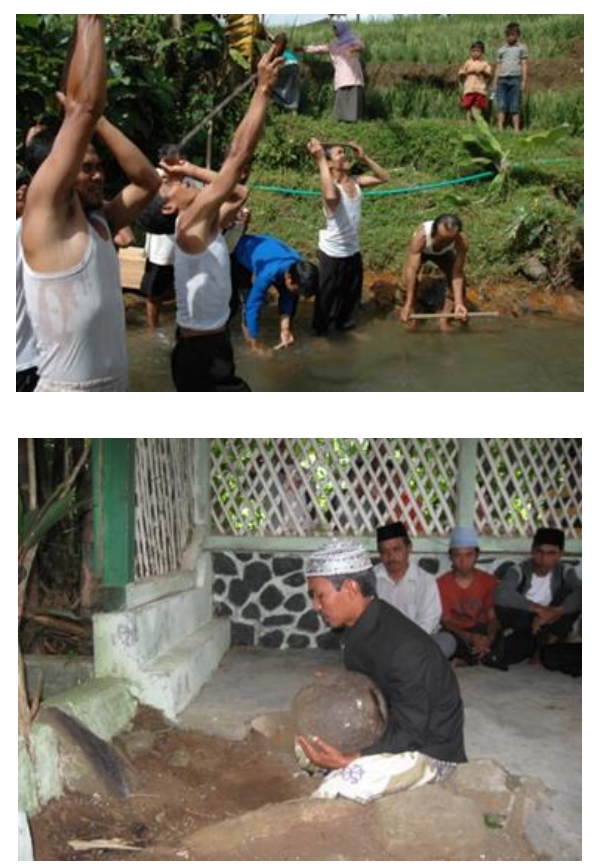

Gambar 5. Warga berebut berkah dari air bekas cucian benda pusaka untuk menyembuhkan sakit mata dan mengangkat batu keramat agar maksudnya terkabul.

Sumber: Dok. penulis, 2010.

Keabsahan atau legitimasi kekuasaan dalam pemikiran masyarakat Desa Dangiang dapat dilihat dari leluhurnya dan kepemimpinan kuncen. Hal ini berkaitan dengan sejarah berdirinya Desa Dangiang. Menurut sejarahnya, Eyang Batara Turus Bawa adalah cikal bakal pendiri Desa Dangiang. Kekuasaan pada masa itu menggunakan kekuasaan religius untuk memerintah dan diwariskan hingga kepada para pemimpin adat yakni kuncen yang masih merupakan keturunannya. Kekuasaan yang dipraktikkan bersumber dari adat leluhurnya dan kuncen memegang peran penting dalam pelaksanaan aturan adat tersebut, sementara rakyat mengikutinya. 
Dalam konteks tersebut Kitaudin (2016) menulis: "Seseorang yang telah menduduki suatu jabatan tertentu, maka ia akan menduduki jabatan tersebut sampai ia meninggal dunia dan diteruskan oleh keturunannya. Oleh sebab itu, mereka berpandangan bahwa kuncen (pemimpin adat) tersebut adalah benar-benar seseorang yang dapat diandalkan”.

Masyarakat Dangiang melihat sumber kekuasaan berasal dari kepercayaannya kepada roh-roh leluhur dan Tuhan, maka dalam pemikiran mereka kekuasaan dipahami sebagai realitas adiduniawi, gaib atau Ilahi. Sumber kekuasaan dari leluhur ini antara lain dimiliki kuncen selaku pemimpin adat. Kuncen menjadi berkuasa dan mulia, karena dapat melindungi warganya. Bagi masyarakat Dangiang, kuncen merupakan pemimpin adat yang menduduki tempat tertinggi dalam struktur masyarakat. Dari silsilah, kuncen masih merupakan keturunan dari leluhur Eyang Batara Turus Bawa. Jabatan kuncen diperoleh melalui garis keturunan yang jatuh pada turunan laki-laki yakni anak laki-laki atau adik laki-laki. Hal ini sangat tergantung pada kesiapan dan kelayakan turunan yang akan menggantikan jabatan sesepuh adat. Kuncen dalam menjalankan tugasnya yang berkaitan dengan adat atau tradisi juga dibantu oleh wakil kuncen. Sebagai pemimpin informal, kuncen juga sering dimintai pendapat dan nasihat dalam rapat formal maupun informal, baik di bidang adat, masyarakat, pembangunan, dan politik.

Seorang kuncen diharapkan mampu berpikir bijak, menjadi panutan, dan melindungi warganya. Hal yang lebih utama adalah seorang kuncen harus mampu menjaga agar tradisi yang telah turun-temurun dilakukan tetap lestari, dapat berjalan selaras dengan agama yang dianut masyarakat dan selaras pula dengan peraturan pemerintah. Pada awalnya, peran kuncen hanya sebagai pemimpin masyarakat pada hal-hal yang berkaitan dengan adat, namun kini tugas kuncen berkembang hampir seluruh aspek kehidupan masyarakat di berbagai aktivitas sosial dan sebagai media pemerintah dalam penyampaian program pembangunan.

Kuncen merupakan lapisan sosial tertinggi berdasarkan keturunan. Saat ini yang menjadi kuncen adalah ajengan Entang dan Bapak Nando sebagai wakil kuncen. Ajengan Entang merupakan keturunan langsung dari kuncen sebelumnya, yakni keturunan generasi ke17. Selain itu, kuncen juga sebagai pemimpin agama yang disebut dengan ajengan. Sebagai pemimpin adat, kuncen bertanggung jawab penuh atas kelangsungan adat istiadat yang ada di Dangiang dan sebagai ajengan bertugas menjadi pemimpin agama. Kuncen juga membantu kades menjalankan roda pemerintahan, khususnya sebagai mediator pemerintah dalam menyampaikan program pembangunan seperti pemilihan kades, $\mathrm{KB}$, perbaikan jalan, kesehatan, pendidikan dan lain sebagainya. Boleh dikata kuncen ini memiliki peran ganda dalam masyarakat. Dalam menjalankan tugasnya, kuncen juga dibantu oleh wakil kuncen. Dalam kehidupan sehari-hari, kuncen menjadi panutan dan tempat bertanya masyarakat, apa yang dikatakan atau dilarang olehnya dipatuhi oleh masyarakat. Kuncen memimpin hampir semua aktivitas pelaksanaan adat istiadat penduduk setempat. Kuncen juga menentukan dan memutuskan semua perkara yang bertalian dengan aturan adat yang harus ditaati semua warga Dangiang. Dalam melaksanakan tata cara kehidupan sehari-hari, masyarakat Dangiang berpegang teguh pada penuturan kuncen yang dianggap sebagai pemimpin tertinggi. Aturan dan tutur kata kuncen sebagai pemimpin adat sangat ditaati oleh masyarakatnya. Oleh sebab itu, kuncen merupakan tempat bertanya, meminta nasihat, dan petunjuk.

Demikianlah kuncen sebagai pemimpin adat di Desa Dangiang, mempunyai peranan penting dalam menjaga tradisi atau adat istiadat. 
Meskipun sistem kepemimpinan pada masyarakat Dangiang terbagi dalam pemimpin formal dan informal, namun peranan pemimpin informal dalam hal ini kuncen memiliki peranan menonjol bila dibandingkan dengan pemimpin formal. Kuncen, selain bertanggung jawab penuh atas kelangsungan adat istiadat, juga membantu Kades menjalankan roda pemerintahan, khususnya sebagai mediator pemerintah dalam menyampaikan program pembangunan. Boleh dikata kuncen ini memiliki peran ganda dalam masyarakat yakni menjalankan aturan adat dan pemerintahan. Dalam menjalankan tugasnya, kuncen juga dibantu oleh wakil kuncen dan menjadi panutan tempat bertanya masyarakat, apa yang dikatakan atau dilarang dipatuhi oleh masyarakat. Menurut Magnis Suseno (2003) hak-hak kekuasaan tersebut diperoleh dari dua sumber yaitu Tuhan yang menurunkan aturan cara tradisional, dimana kekuasaan dipahami sebagai partisipasi dari kekuatan alam gaib atau adikodrati, kekuasaan itu berpartisipasi dalam kemutlakan haknya. Legitimasi religius, yang menyandarkan kekuasaan kepada kekuatan ilahiah dan roh leluhur dalam konsepsi pemikiran masyarakat Dangiang dengan melihat kemampuan seorang penguasa atau pemimpin menjalankan kekuasaannya, yaitu kepandaiannya, kepintarannya, kemampuannya menjalin relasi dengan penguasa adikodrati, kebijaksanaannya, dan tidak menyimpang dari kaidah-kaidah atau aturan yang berlaku. Prasyarat tersebut melekat dalam legitimasi religius terhadap pemimpin adat kuncen sebagai pelindung. Kekuasaan yang adikodrati, ilahiah dan religius kerapkali berhubungan dengan hal-hal yang mistik atau supranatural, dan secara umum memerlukan suatu konsep simbol kekuasaan. Simbol-simbol yang dihadirkan dalam upacara Siraman dan ngalunsur geni menjadi peranti untuk memproduksi kekuasaan. Penciptaan simbol untuk melegitimasi kekuasaan, lebih efektif daripada melalui paksaan. Dengan kata lain, kekuasaan bisa lebih efektif didapatkan melalui cara-cara yang halus (manipulatif dan hegemoni) ketimbang represif. Sebab, kata Foucault, paksaan lebih sering membuat orang memberontak daripada menurut,

Simbol kekuasaan bertumpu pada benda-benda pusaka yang dianggap sakti dan mengandung makna di dalamnya. Simbol-simbol keabsahan dan legitimasi kekuasaan melekat pada diri penguasa tatkala penguasa mampu menunjukkan diri sebagai pemimpin dan rakyat tunduk padanya. Hal ini digambarkan oleh sosok kuncen yang mampu menerapkan aturan adat yang diturunkan Tuhan untuk mewujudkan kehidupan masyarakat Dangiang yang tenteram, aman, tertib, dan teratur. Dengan demikian, keabsahan atau legitimasi kekuasaan dalam pemikiran masyarakat Dangiang terkait dengan halhal religius, ilahiah, dan bertumpu pada simbol kekuasaan leluhur Eyang Batara Turus Batara dan benda-benda pusaka. Di balik faktor tersebut terkandung adanya kewibawaan penguasa, percaya diri, dan kharisma, sebagai pusat kekuasaan yang utama, menyeluruh, dan mulia. Legitimasi tersebut oleh Magnis Suseno disebut legitimasi religius. Dalam konsepsi masyarakat Dangiang menganggap pemimpin yang ideal berasal dari garis keturunan leluhur yakni kuncen. Kuncen Dangiang yang bernama Ajengan Entang dianggap merupakan keturunan terakhir dari Sembah Dalem Tanu Datar. Kuncen menduduki tempat tertinggi dalam struktur masyarakat Desa Dangiang. Sembah Dalem Tanu Datar ini adalah cucu dari Eyang Batara Turus Bawa, cikal bakal pendiri Desa Dangiang.

Berkenaan dengan peranan 'leluhur', maka perlu dikemukakan satu konsep pemujaan leluhur yaitu konsep keluhuran. Keluhuran adalah segala sifat yang bernilai mulia, agung, halus, dan tinggi. Sifat yang dimiliki oleh leluhur ini mengakibatkan masyarakat selalu melakukan kontak dengannya agar mendapatkan berkah keselamatan. Prinsip 
konsep keluhuran sama dengan prinsip kedewaan atau ke-Tuhanan, karena mencirikan sesuatu yang mengawang mutlak di atas situasi aktual dan seolaholah bebas di luar jangkauan panca indra manusia. Dalam sistem kepercayaan pemujaan kepada leluhur, bagi masyarakat pedesaan termasuk juga Desa Dangiang, leluhur (karuhun) dianggap mempunyai otoritas karena dianggap mampu melindungi dan memecahkan segala persoalan manusia. Dengan demikian leluhur menduduki posisi supra dan masuk dalam puncak hierarki tata alam semesta.

Prinsip di atas, sama dengan konsep berpikir dalam struktur model buatan Leach, yakni menempatkan leluhur atau Tuhannya dalam puncak hierarki tata alam semesta. Dalam hal ini, Eyang Gusti Batara Turus Bawa dianggap sebagai leluhur yang harus dihormati dan diletakkan pada puncak hierarki tata alam semesta. Sedangkan manusia (masyarakat) terletak di bawah susunan tata alam semesta. Maka untuk mencapai keselarasan atau keharmonisan tata alam semesta ini, dibuat jembatan sebagai mediator yang menghubungkan leluhur (dunia sana) dengan manusia (dunia sini), yakni dengan melakukan upacara (ritual atau selamatan).

Taylor dalam Rostiyati (2017), mengemukakan bahwa tumbuhnya religi umat manusia berpangkal pada keyakinan terhadap adanya jiwa atau soul sebagai substansi yang menyebabkan adanya kehidupan. Apabila manusia itu mati, jiwa atau soul itu tetap hidup dan bertempat tinggal pada tempat-tempat tertentu. Jiwa yang melepaskan diri dari badan wadaq itu dapat berbuat baik maupun buruk terhadap manusia. Sedangkan roh atau spirit tidak kembali lagi pada wadaq tersebut. Pernyataan Taylor tersebut, sesuai dengan kepercayaan yang dianut sebagian besar masyarakat di Indonesia, di dalam berhadapan dengan dunia sekitarnya. Adanya istilah "keramat' yang diperuntukkan bagi tempat-tempat atau benda-benda tertentu, dianggap sebagai tempat spirit yang ada di sekitar manusia. Sudah barang tentu, makam-makam dan benda-benda yang dikeramatkan tersebut memiliki latar belakang yang unik, misalnya sejarah hidup orang dan bendabenda yang dikeramatkan tersebut dianggap sangat luar biasa.

Demikian pula halnya yang dilakukan oleh masyarakat Desa Dangiang, Eyang Gusti Batara Turus Bawa dan benda-benda pusaka peninggalannya, dianggap keramat dan dihormati sebagai tokoh suci dan benda-benda pusaka yang mempunyai pengaruh besar pada mayarakatnya. Latar belakang sejarah hidupnya dalam membuka pertama kali Desa Dangiang, telah mengokohkan kepercayaan masyarakat setempat, akan tuah dan keramat makam leluhur serta benda-benda peninggalannya. Sebagai bentuk penghormatan, maka dilakukan upacara yang disebut dengan Siraman dan Ngalungsur Geni.

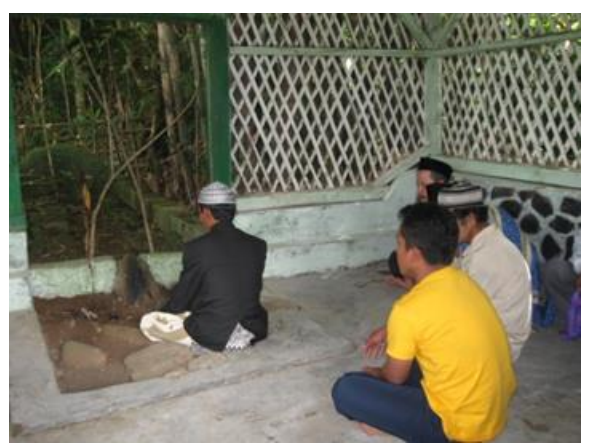

Gambar 6. Kuncen dan wakil kuncen memimpin doa.

Sumber: Dok. penulis, 2010.

\section{PENUTUP}

Kekuasaan dalam pelaksanaan upacara Siraman dan Ngalungsur Geni, tampaknya dikonstruksi secara dinamis. Kekuasaan awalnya tampak statis karena terpusat pada pemimpin ritual semata yakni kuncen, tapi didistribusi merata pada semua warga peserta upacara. Simbol dari distribusi kekuasaan adalah semua peserta merasakan adanya keberkahan yang didapat dari doa kuncen di makam dan air bekas cucian benda-benda pusaka Eyang 
Batara Turus Bawa, leluhur Desa Dangiang. Interpretasi terhadap pelaksanaan upacara adat Siraman dan Ngalungsur Geni menunjukkan bahwa ritual komunal dalam kehidupan masyarakat Dangiang yang dilakukan secara temporal tidak luput dari kepentingan. Dalam hal ini mendistribusikan kekuasaan yang terpusat pada kepemimpinan adat Kuncen dan leluhur Eyang Batara Turus Bawa untuk menciptakan kekuasaan baru yang dirasakan oleh semua warga peserta upacara. Selain itu, melalui ritual, pada satu sisi kuasa diproduksi dan pada sisi yang lain kuasa juga dapat dikonstruksi.

Pada upacara Siraman dan Ngalungsur Geni, kekuasaan diproduksi melalui kehadiran figur tertentu (kuncen, wakil kuncen, tokoh masyarakat) yang kehadirannya menyebabkan para peserta merasa memiliki kekuatan ekstra atas keberkahan yang didapat dari air bekas cucian benda pusaka dan doa mantra dari kuncen, yang menyiratkan kekuasaan tertentu. Wujud dari kehadiran para pemimpin dan sesepuh desa dan bendabenda pusaka tersebut membuat warga peserta upacara mengalami adanya kekuatan untuk sembuh dari penyakitnya, selamat dari petaka, sehat, dan berhasil usaha, pendidikan dan kariernya, serta mampu mengangkat batu besar. Kekuasaan yang dikonstruksi di sini tidak statis dan tidak memiliki kekuasaan secara politik yang bisa mengkontrol perilaku kehidupan orang. Melainkan, seperti kata Foucalt dapat disebut sebagai kekuasaan dinamis, tidak terpusat pada satu sumber otoritas, karena kekuasaan datang dari mana-mana, dan tidak bisa dilihat dari seseorang yang menguasai orang lain.

Dalam hal ini pemimpin adat kuncen tidak menguasai masyarakat, tapi masyarakat sangat percaya bahwa kuncen adalah keturunan leluhur, sesuatu yang dianggap penting untuk dihormati. Kekuasaan kuncen tidak bekerja secara negatif dan represif melainkan dengan cara positif dan produktif. Apa yang disampaikan kuncen, terdapat nilai-nilai budaya dan edukasi bagi masyarakat Dangiang untuk hidup bersih, menghormati leluhur, adanya persatuan warga dengan doa dan makan bersama, adanya pantangan dan sesaji yang mengandung makna. Dengan kesadaran diri warga mematuhi aturan adat yang sudah dilakukan selama ini. Pengaruh daya yang ada atau timbul dari sesuatu (orang, benda) ikut membentuk watak, kepercayaan, atau perbuatan seseorang (Anderson, 2015: 22).

Siraman dan Ngalungsur Geni dengan sendirinya memiliki makna religius dan sakral dalam kehidupan masyarakat Dangiang. Di sini masyarakat Dangiang menegaskan identitas kultural mereka sebagai bagian dari komunitas adat di Garut yang tetap konsisten dengan kepatuhan terhadap aturan adat. Sisi lain mereka juga patuh terhadap identitas mereka sebagai bagian dari kelompok keagamaan yang universal (Islam). Dalam perspektif ini, dialektika adat dan agama menjadi menarik dan penting dalam kontruksi kekuasaan yang diproduksi oleh pemimpin adat kuncen, karena kuncen di sini juga dianggap sebagai ajengan (kiai) di Garut. Sebagai tokoh agama dan adat, tentu menjadi figur penting dan berperan dalam masyarakat Dangiang.

\section{DAFTAR SUMBER}

Abdullah, I. (2009). Dinamika Masyarakat dan Kebudayaan Kontemporer. Yogyakarta: Pustaka Pelajar.

Anderson, B. (2015). Imagined Communities. Jakarta: Pustaka pelajar.

Bae, S.U. dan Martinus. (1995). Laporan penelitian: Sejarah Suku Dayak Maanyan, Banjar, dan Merina di Madagaskar. Jakarta: Museum Nasional RI.

Barker, C. (2010). Cultural Studies. Yogyakarta: Kreasi Wacana.

Barthes, R. (1985). Elemens of Semiologi. London: Cape.

Bourdieu, P. (1994). Language and Symbolic Power. Cambridge, Massachausetts: 
Harvard University Press.

Durkheim, E. (2005). Education and Sociology. Jakarta: Kencana.

Danesi M. (2004). Pesan, Tanda, Makna. Yogyakarta: Jalasutra.

Foucault, M. (2002). Pengetahuan dan Metode: Karya-karya Penting Foucalt. Yogyakarta: Jalasutra.

Hadi, K. (2018). Legitimasi Kekuasaan dan Hubungan Penguasa-Rakyat dalam Pemikiran Politik Suku Dayak Maanyan. Kawistara, 8(1), 46-50.

Kitaudin, S. (2016). Kekuasaan Negara dan Kekuasaan Pemerintahan. Tapls, 12 (1) 70-71.

Magnis-Suseno, F. (2003). Etika Politik; Prinsip-Prinsip Moral Dasar Kenegaraan Modern. Jakarta : PT. gramedia.

Mudhoffir, A. (2013). Teori Kekuasaan Michel Foucault: Tantangan bagi Sosiologi Politik. Al-Khitabah, 18 (1), 4-6.

Muis, E. (2010). Tumbuhnya Maronere: Relasi Antara Budaya dan Falsafah Hidup Masyarakat Moronere. Tesis Program Studi Antropologi, Pascasarjana UGM Yogyakarta.

Rostiyati, A. (2017). Peran Perempuan pada Upacara Tradisional Rahengan di Desa Citatah, Kabupaten Bandung Barat. Patanjala. Vol. 9 No. 3 September 2017. Hlm. 360.

Rostiyati, A. (2011). Upacara Siraman dan Ngalungsur Geni di Desa Dangiang Kabupaten Garut. Patanjala, Vol. 3 No.1 Maret. Hlm. 33-47.

Rostiyati, A. (2017). Perempuan Punk: Budaya Perlawanan terhadap Gender Normatif. Tesis Fakultas Ilmu Budaya Universitas Padjadjaran.

Somantri, G,R. (2005). Memahami Metode Kualitatif. Sosial. Humaniora Makara,.9 (2). 64.

Turner, V. (1967). The Forest Of Symbols: Aspects of Ndebu Ritual. London: Cornell University Press.

Usop, KMA. (1978). Laporan Penelitian: Sejarah Daerah Kalimantan Tengah:
Proyek Penelitian Kebudayaan RI dan Dinas Pendikan dan Kebudayaan Provinsi Kalimantan Tengah. 